\title{
Characteristics of trace gaseous pollutants at a regional background station in Northern China
}

\author{
Z. Y. Meng, X. B. Xu, P. Yan, G. A. Ding, J. Tang, W. L. Lin, X. D. Xu, and S. F. Wang \\ Key Laboratory for Atmospheric Chemistry, Center for Atmosphere Watch and Services, Chinese Academy of \\ Meteorological Sciences, Beijing 100081, China
}

Received: 22 February 2008 - Published in Atmos. Chem. Phys. Discuss.: 23 May 2008

Revised: 4 November 2008 - Accepted: 4 November 2008 - Published: 5 February 2009

\begin{abstract}
Measurements of trace gaseous pollutants were taken at the Shangdianzi site, a WMO Global Atmosphere Watch (GAW) background station in Northern China. The results are presented for the period from September 2003 to December 2006. Seasonal and diurnal variations of the $\mathrm{O}_{3}$, $\mathrm{NO}_{\mathrm{x}}, \mathrm{SO}_{2}$, and $\mathrm{CO}$ concentration are characterized and possible causes for them are discussed. The observed levels of the trace gases are comparable to those at some other background sites in polluted regions inside and outside of China. It was shown that the seasonal variation of $\mathrm{O}_{3}$ can change slightly from year to year due to the year-to-year alternation in the meteorological conditions. Higher CO concentrations were observed in some warmer months, particularly in June and July, 2006. Intensive biomass burning in the North China Plain region, in combination with the transport of regional pollution by more frequent southwesterly winds, is believed to be responsible for the elevated $\mathrm{CO}$ concentrations. The diurnal variation of $\mathrm{O}_{3}$, with delayed peaking times, suggests that the transport of photochemical aged plume is an important source for $\mathrm{O}_{3}$ at Shangdianzi. The diurnal variations of $\mathrm{SO}_{2}$ in all seasons show higher values during daytime, contradicting the common view. An explanation for this unusual phenomenon is hypothesized. To gain an insight into the impact of transport on the trace gases levels at Shangdianzi, air mass backward trajectories were calculated and analyzed in combination with corresponding pollutant concentrations. The results indicate that the transport of air masses from the North China Plain region and from the major coal mining regions west of Shangdianzi is responsible for the high concentrations of the gaseous pollutants.
\end{abstract}

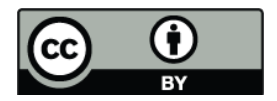

Correspondence to: Z. Y. Meng (mengzy@cams.cma.gov.cn)

\section{Introduction}

Human activities have exerted large impacts on the global environment. Anthropogenic emissions of gaseous and particulate matters have been altering the levels of many atmospheric species, causing air pollution, climate change, and other environmental problems. Air pollution has become one of the important factors affecting public health (Ostro, 2004) and its influences can be of a regional scale or even a global scale (Lelieveld et al., 2002). Changes in the atmospheric compositions have very likely caused the observed global warming (Forster et al., 2007). Large increases in anthropogenic emissions of the photochemical precursors, $\mathrm{NO}_{\mathrm{x}}$ in particular, have caused substantial increases in the global background $\mathrm{O}_{3}$ mixing ratios over the past century (Jaffe et al., 2003; Marenco et al., 1994). Acid rain has already been recognized as a regional-scale environment problem in China, and $\mathrm{SO}_{2}$ is the most important precursor (Wang and Wang, 1995; Wang et al., 2001a; Zhao et al., 1988). CO has an effect on the oxidization of the atmosphere through interaction with hydroxyl radical $(\mathrm{OH})$, which also reacts with methane, halocarbons and tropospheric ozone.

Observation of the changes in background atmospheric composition is an essential way to understand the influence of human activities on the atmospheric environment and global change (Fischer et al., 2003; Jaffe et al., 2003; Jaffe and Ray., 2007; Meng et al., 2007; Tang et al., 2007; Yan et al. 2008). Campaigns have been carried out in the Yangtze Delta and Pearl River Delta, China (Wang et al., 2001a, b; 2003a, b; Xu, et al., 2008), showing significant impacts of human activities on the regional air quality. Some studies focused on major gaseous pollutants in Northern China (Ding et al., 2002, 2008; Hao et al., 2005; Ma et al., 2004; 2006; Meng et al., 2002, 2008; Wang et al., 2006; Xie et al., 2005; $\mathrm{Xu}$ et al., 2005). So far, field measurements of key air pollutants in rural locations in Northern China are comparatively

Published by Copernicus Publications on behalf of the European Geosciences Union. 
sparse. In this paper, we present measurements of the key reactive gases, i.e., $\mathrm{O}_{3}, \mathrm{NO}_{\mathrm{x}}, \mathrm{SO}_{2}$, and $\mathrm{CO}$, from a background station in North China, characterize the levels and variations of the gases in the background area of Northern China, discuss the sources and factors affecting the concentrations of these gases.

\section{Description of experiment}

\subsection{Measurement site}

The Shangdianzi station (SDZ, $40^{\circ} 39^{\prime} \mathrm{N}, 117^{\circ} 07^{\prime} \mathrm{E}$, $293.3 \mathrm{~m}$ a.s.1.) is located in the northeast of Beijing, with a distance of about $150 \mathrm{~km}$ to the urban area of Beijing. Beijing sits in the northern edge of the North China Plains, with a population of more than 15.8 million in 2006 (Beijing Municipal Bureau of Statistics, http://www.bjstats.gov.cn. About $55 \mathrm{~km}$ southwest of SDZ is the nearest township, Miyun town, with a population of about 0.426 million. Within $30 \mathrm{~km}$ of the site, there are only small villages in mountainous areas with a sparse population and thus an insignificant anthropogenic emission source. Surrounding the site, fruit trees and corn are grown in the slope fields.

SDZ is one of the WMO/GAW regional background stations in China. Located on the north edge of the North China Plain, the station is setup to capture the atmospheric background data of the North China Plain. Figure 1 shows the location of SDZ and some cities like Beijing, Tianjin, Tangshan, Zhangjiakou, etc. surrounding the SDZ site in Northern China. The northern regions of SDZ are much less inhabited, encompassing of the vast grassland of Inner Mongolia and mountainous rural regions of Hebei province, where the population is relatively sparse and the industrial activities are less prevalent.

\subsection{Instrumentation}

A set of commercial instruments have been used for continuous observation of the reactive gases. $\mathrm{O}_{3}$ was measured with a UV photometric analyzer (Thermo Environmental Instruments (TEI), Inc., model 49C). $\mathrm{NO}, \mathrm{NO}_{2}$ and $\mathrm{NO}_{\mathrm{x}}$ were measured with a chemiluminescence analyzer (TEI, model $42 \mathrm{CTL}$ ), and $\mathrm{SO}_{2}$ was measured by using a pulsed UV fluorescence analyzer (TEI, model 43CTL). CO was measured with a gas filter correlation analyzer (TEI, model 48C). All instruments were housed in an air-conditioned room. Ambient air is sucked from $1.8 \mathrm{~m}$ above the rooftop of the room through a stainless steel manifold using a ventilator and is introduced to the Teflon sample inlets of the instruments. The residence time of air in the manifold is about $20 \mathrm{~s}$. Automatic zero and span checks were done everyday to check for possible analyzer malfunction and calibration drift. More frequent zero checks (every $6 \mathrm{~h}$ ) for $\mathrm{CO}$ analyzer were carried out because of the inherent zero drift of this type of $\mathrm{CO}$ analyzer. The multi-point calibrations were performed

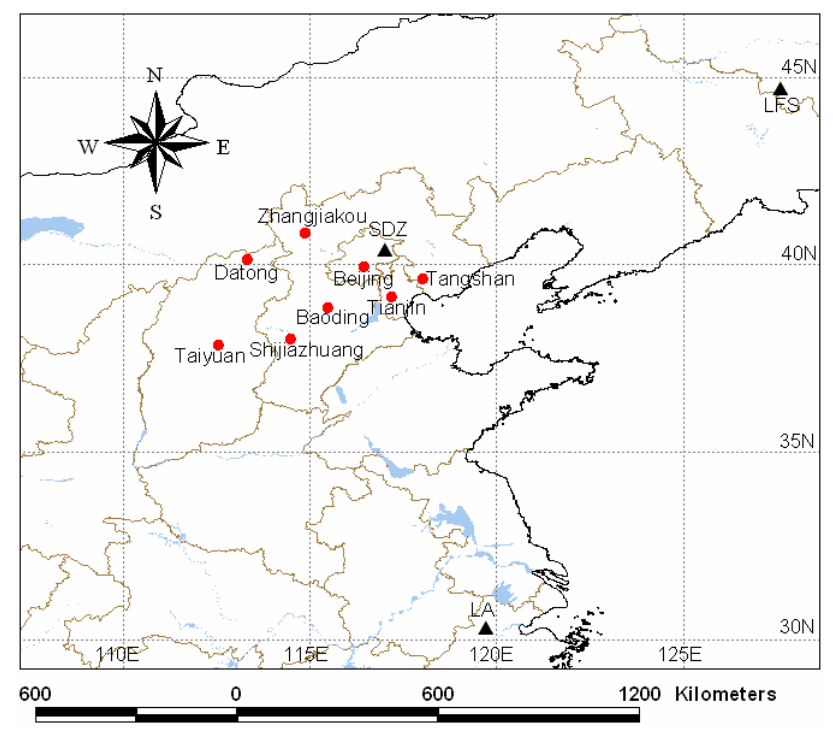

Fig. 1. Location of the Shangdianzi (SDZ), Lin'an (LA) and Longfenshan (LFS) regional background stations of China, and some cities in Northern China.

at approximately 3-month interval, and before or after any adjustments are taken on the instruments. Reference $\mathrm{SO}_{2}$, NO, and CO gas mixtures (National Institute of Metrology, Beijing, China) have been used for span checks and multipoint calibrations of the $\mathrm{SO}_{2}, \mathrm{NO}_{\mathrm{x}}$, and $\mathrm{CO}$ analyzers, respectively. The $\mathrm{O}_{3}$ analyzer has been span-checked using an $\mathrm{O}_{3}$ source from the dynamic gas calibration system (TEI 146C) and calibrated using $\mathrm{O}_{3}$ Primary Standard Calibrator (TEI 49CPS), which are traceable to the Standard Reference Photometer (SRP) maintained by WMO World Calibration Centre in Switzerland. Five-minute average data were stored in the data logger and hourly averaged values are presented in this paper.

\section{Results and discussion}

3.1 Observed levels and comparisons with data from other background sites

The statistics of concentrations of trace gases measured at the SDZ site are shown in Table 1. From September to December 2003 , the average concentration in ppbv was $26.8 \pm 13.9$ for $\mathrm{O}_{3}, 0.7 \pm 1.8$ for $\mathrm{NO}, 10.1 \pm 7.9$ for $\mathrm{NO}_{2}, 10.8 \pm 8.8$ for $\mathrm{NO}_{\mathrm{x}}$, $2.2 \pm 3.6$ for $\mathrm{SO}_{2}$ and $505 \pm 335$ for $\mathrm{CO}$. The annual mean $\mathrm{O}_{3}$ mixing ratio varied from $30.1 \pm 21.0 \mathrm{ppbv}$ to $32.8 \pm 19.1 \mathrm{ppbv}$ during 2004-2006. The annual mean NOx concentration were $14.5 \pm 14.0,11.0 \pm 11.3$ and $12.7 \pm 11.8 \mathrm{ppbv}$ in 2004 , 2005 , and 2006, respectively. The corresponding $\mathrm{SO}_{2}$ values were $5.9 \pm 10.0,6.1 \pm 9.9$ and $7.6 \pm 10.2 \mathrm{ppbv}$ in 2004,2005 and 2006, respectively, showing an increasing trend over the period from 2004 to 2006 . The annual mean CO level 
Table 1. Statistics results of the measured trace gaseous pollutants during 2003-2006 at SDZ, China.

\begin{tabular}{llllllll}
\hline Time & & $\mathrm{O}_{3}$ & $\mathrm{NO}$ & $\mathrm{NO}_{2}$ & $\mathrm{NO}_{\mathrm{x}}$ & $\mathrm{SO}_{2}$ & $\mathrm{CO}$ \\
\hline 2003.9-2003.12 & Mean & 26.8 & 0.7 & 10.1 & 10.8 & 2.2 & 505 \\
& Median & 27.7 & 0.1 & 8.3 & 8.8 & 0.8 & 420 \\
& $\mathrm{SD}$ & 13.9 & 1.8 & 7.9 & 8.8 & 3.6 & 335 \\
& Minimum & 0.1 & 0.05 & 0.5 & 0.5 & 0.1 & 50 \\
& Maximum & 99.9 & 27.7 & 53.0 & 57.0 & 27.4 & 1730 \\
& No. of points & 1852 & 1858 & 1852 & 1858 & 1852 & 811 \\
2004.1-2004.12 & Mean & 30.1 & 0.8 & 13.8 & 14.5 & 5.9 & \\
& Median & 26.7 & 0.05 & 9.5 & 10.1 & 1.5 & \\
& SD & 21.0 & 2.0 & 13.1 & 14.0 & 10.0 & \\
& Minimum & 1.0 & 0.05 & 0.05 & 0.1 & 0.1 & \\
& Maximum & 155.7 & 25.5 & 97.0 & 106.2 & 92.1 & \\
& No. of points & 8038 & 8244 & 8244 & 8245 & 8242 & \\
& Mean & 32.8 & 2.5 & 8.5 & 11.0 & 6.1 & 586 \\
& Median & 30.4 & 2.8 & 5.3 & 7.4 & 2.3 & 495 \\
& SD & 19.1 & 1.7 & 10.6 & 11.3 & 9.9 & 415 \\
& Minimum & 0.1 & 0.05 & 0.05 & 1.0 & 0.1 & 50 \\
& Maximum & 135.2 & 30.5 & 121.8 & 147.6 & 87.4 & 3123 \\
& No. of points & 8648 & 8169 & 8169 & 8169 & 8672 & 5173 \\
Mean $005.1-2006.12$ & 30.9 & 1.3 & 11.5 & 12.7 & 7.6 & 742 \\
& Median & 29.3 & 1.1 & 8.1 & 9.0 & 3.3 & 612 \\
& SD & 19.8 & 1.9 & 10.8 & 11.8 & 10.2 & 558 \\
& Minimum & 0.1 & 0.05 & 0.05 & 0.1 & 0.1 & 50 \\
& Maximum & 153.5 & 25.9 & 77.8 & 93.3 & 83.6 & 3920 \\
& No. of points & 8593 & 8421 & 8421 & 8421 & 8469 & 8381 \\
\hline & & & & & & &
\end{tabular}

SD: standard deviation.

changed from $586 \pm 415 \mathrm{ppbv}$ in 2005 to $742 \pm 558 \mathrm{ppbv}$ in 2006. It can be seen in Table 1 , NO concentrations are very low at the SDZ station, and $\mathrm{NO}_{\mathrm{x}}$ exist mainly in the form of $\mathrm{NO}_{2}$, representing the character of the cleaner region.

Levels of pollutants at a regional background station are closely related to the regional population density, industrial activities, efficiency of emission control, etc. To gain a better understanding of air quality of the SDZ area, monthly mean levels of $\mathrm{SO}_{2}, \mathrm{NO}_{2}, \mathrm{CO}$, and $\mathrm{O}_{3}$ at SDZ are compared with those observed at some other regional background stations in China and other countries at similar latitudes (Table 2). In China, there are another two WMO/GAW regional background stations, i.e., Lin'an $\left(\mathrm{LA}, 30.18^{\circ} \mathrm{N}\right.$, $119.44^{\circ} \mathrm{E}, 138.6 \mathrm{~m}$ a.s.1.) and Longfengshan (LFS, $44^{\circ} 73^{\prime} \mathrm{N}$, $127^{\circ} 60^{\prime} \mathrm{E}, 310.0 \mathrm{~m}$ a.s.l.). The locations of these stations are also marked in Fig. 1. The LA station is situated on the southern edge of the Yangtze Delta region, which is a densely populated and fast developing region.

LFS is a remote site in China's Northeast Plain, a sparsely populated and underdeveloped region. Data in Table 2 indicate that the SDZ site is as polluted as the Lin'an site in terms of the reactive gases and is much more polluted than the LFS site in terms of primary gases. It is not surprising that the background levels of pollutants at SDZ are so high because the North China Plain region, which encompasses the city cluster Beijing-Tianjin-Bohai Bay, is an economically vibrant and densely populated region.

As can be seen in Table 2, the monthly mean $\mathrm{NO}_{2}$ concentrations at Shangdianzi are higher than those measured at Longfengshan, China, and Pleven, Bulgaria, but much lower than those measured at Burgas, Bulgaria. The monthly mean $\mathrm{SO}_{2}$ concentrations at Shangdianzi are close to the median level among all stations with $\mathrm{SO}_{2}$ values in Table 2. The monthly mean CO concentrations at Shangdianzi are close to those measured at Lin'an, China, significantly higher than those measured at Longfengshan, China, and much higher than those measured at Ryori, Janpan. The differences of the monthly mean $\mathrm{O}_{3}$ concentrations among the stations are not as large as those of primary pollutants concentrations. However, it is noticeable that among all sites listed in Table 2, Shangdianzi shows the largest variability of $\mathrm{O}_{3}$. Such large variability is caused by strong influences from emissions in the North China Plain and by the contrast air masses (Lin et al., 2008).

\subsection{Seasonal variations}

The monthly mean concentrations of $\mathrm{O}_{3}, \mathrm{NO}_{\mathrm{x}}, \mathrm{SO}_{2}$, and $\mathrm{CO}$ at SDZ are shown in Fig. 2. The $\mathrm{O}_{3}, \mathrm{NO}_{\mathrm{x}}$, and $\mathrm{SO}_{2}$ data cover the period from September 2003 to December 2006, 
Table 2. Comparison with the observations made at other sites (monthly value).

\begin{tabular}{lllllll}
\hline Station & Location & Period & $\begin{array}{l}\mathrm{O}_{3} \\
(\mathrm{ppbv})\end{array}$ & $\begin{array}{l}\mathrm{NO}_{2} \\
(\mathrm{ppbv})\end{array}$ & $\begin{array}{l}\mathrm{SO}_{2} \\
(\mathrm{ppbv})\end{array}$ & $\begin{array}{l}\mathrm{CO} \\
(\mathrm{ppbv})\end{array}$ \\
\hline Shangdianzi, China $^{\mathrm{a}}$ & $40.39^{\circ} \mathrm{N}, 117.07^{\circ} \mathrm{E}, 293.3 \mathrm{~m}$ & Sep 2003-Dec 2006 & $13.8-52.1$ & $1.7-27.5$ & $0.1-15.2$ & $430-923$ \\
Lin'an, China $^{\mathrm{a}}$ & $30.18^{\circ} \mathrm{N}, 119.44^{\circ} \mathrm{E}, 138.6 \mathrm{~m}$ & Jul 2005-Nov 2006 & $17.5-44.8$ & $6.6-24.0$ & $8.6-27.1$ & $501-948$ \\
Longfengshan, China $^{\mathrm{a}}$ & $44.73^{\circ} \mathrm{N}, 127.60^{\circ} \mathrm{E}, 310.0 \mathrm{~m}$ & Jul 2005-Nov 2006 & $25.2-47.3$ & $0.9-8.8$ & $0.4-5.8$ & $169-591$ \\
Burgas,Bulgaria $^{\mathrm{b}}$ & $42.48^{\circ} \mathrm{N}, 27.48^{\circ} \mathrm{E}, 16 \mathrm{~m}$ & Jan 1990-May 2006 & & $1.6-43.0$ & $0.4-19.5$ & \\
Pleven,Bulgaria $^{\mathrm{b}}$ & $43.42^{\circ} \mathrm{N}, 24.60^{\circ} \mathrm{E}, 64 \mathrm{~m}$ & Jan 1990-May 2006 & & $1.1-19.1$ & $0.4-37.4$ & \\
Ryori, Janpan $^{\mathrm{b}}$ & $39.03^{\circ} \mathrm{N}, 141.82^{\circ} \mathrm{E}, 260 \mathrm{~m}$ & Jan 1991-Sep 2006 & $23.1-56.9$ & & & \\
Trinidad Head, USA $^{\mathrm{b}}$ & $41.05^{\circ} \mathrm{N}, 124.15^{\circ} \mathrm{W}, 120 \mathrm{~m}$ & Apr 2002-May 2005 & $22.7-44.9$ & & & \\
\hline
\end{tabular}

a This work.

b WMO, 2007

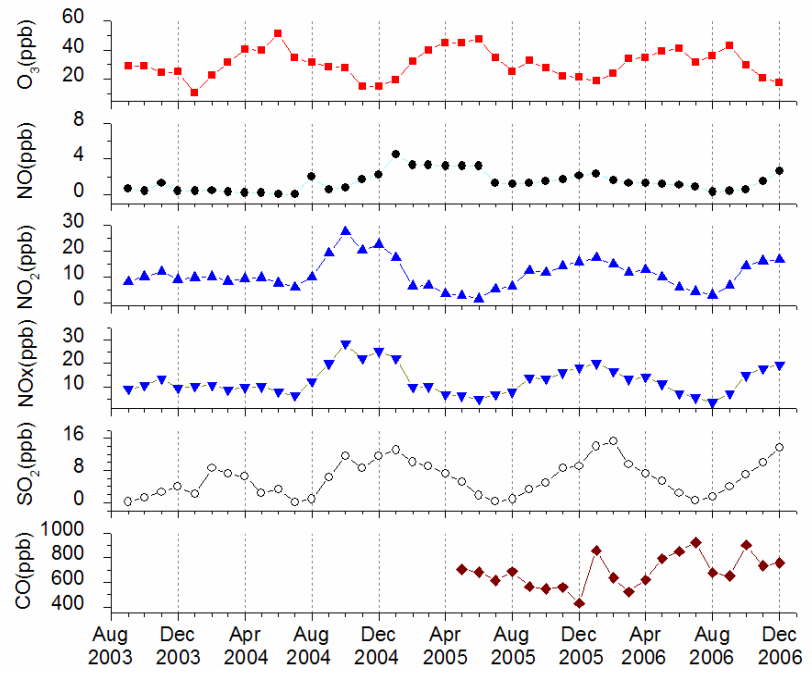

Fig. 2. Monthly average concentrations of trace gases at SDZ during 2003-2006.

while the CO data cover the period from May 2005 to December 2006. The $\mathrm{O}_{3}$ concentration shows higher values in the warmer months and lower values in the colder months. The maximal monthly mean $\mathrm{O}_{3}$ concentrations in 2004, 2005, and 2006 were $51.2 \mathrm{ppbv}$ (June), $47.1 \mathrm{ppbv}$ (June), and $43.2 \mathrm{ppbv}$ (September), respectively.

The seasonal $\mathrm{O}_{3}$ pattern changed from year to year. For example, the monthly mean $\mathrm{O}_{3}$ concentration in 2004 peaked only in June, while in 2005 and $2006 \mathrm{O}_{3}$ peaked in June and September. This year-to-year variation in the seasonal cycle may be due to year-to-year alternation in the meteorological conditions (Wang et al., 2001b). On average, the seasonal variation of $\mathrm{O}_{3}$ at $\mathrm{SDZ}$ shows a double-peak pattern, with the primary and secondary peaks being in June and September, respectively. This seasonal pattern reflects the contribution of photochemical production of $\mathrm{O}_{3}$ during the period of intensive solar radiation and the influences of Asian monsoon, which brings more clouds and rainfall, and causes lower $\mathrm{O}_{3}$ in July and August (Wang et al., 2001b; Wang et al., 2008; Xu et al., 2008).

The monthly mean concentration of $\mathrm{NO}_{\mathrm{x}}$ ranged from $3.5 \mathrm{ppbv}$ in August 2006 to $28.3 \mathrm{ppbv}$ in October 2004 and that of $\mathrm{SO}_{2}$ ranged from $0.1 \mathrm{ppbv}$ in July 2004 to $15.2 \mathrm{ppbv}$ in February 2006. On the average, $\mathrm{NO}_{\mathrm{x}}$ and $\mathrm{SO}_{2}$ showed a pattern of higher concentration in winter and lower concentration in summer. This kind of seasonal cycle is attributable to the seasonal differences in photochemical reduction, removal by rainfall, vertical mixing, etc. Being a station in the middle latitudes in Eastern Asia, SDZ can be characterized by cold/dry winter and hot/humid summer. Precipitation in the areas surrounding SDZ occurs mainly in the summer months. For example, in 2006 about $85 \%$ of annual precipitation in the Beijing region occurred in July and $\mathrm{Au}-$ gust. Therefore, the $\mathrm{NO}_{\mathrm{x}}$ and $\mathrm{SO}_{2}$ concentrations at $\mathrm{SDZ}$ in summer are lowered by more rapid photochemical reduction, more removal by rainfall, and better vertical mixing. In winter, the concentrations of these gases increase due to smaller removal, strong inversion, and increased emission from heating sources.

The seasonal pattern of $\mathrm{CO}$ looks quite different from those of $\mathrm{NO}_{\mathrm{x}}$ and $\mathrm{SO}_{2}$. There are more fluctuations in the seasonal cycle of $\mathrm{CO}$ than those of $\mathrm{NO}_{\mathrm{x}}$ and $\mathrm{SO}_{2}$ and the seasonal trend of $\mathrm{CO}$ is inconsistent with those of $\mathrm{NO}_{\mathrm{x}}$ and $\mathrm{SO}_{2}$. High monthly mean $\mathrm{CO}$ concentrations occurred in some warmer months (e.g., June, July, and October, 2006), when $\mathrm{NO}_{\mathrm{x}}$ and $\mathrm{SO}_{2}$ were low.

The elevated CO levels at SDZ may be attributed to the transport of regional pollution and also to more intense biomass burning activities in the North China Plain. Very intensive biomass burning occurs during the harvest periods in some major Chinese agricultural regions, such as the North China Plain, leading to higher CO levels. Similar patterns of monthly mean $\mathrm{CO}$ and $\mathrm{O}_{3}$ levels were also observed at the Miyun site (about $50 \mathrm{~km}$ from SDZ) in the summer of 2006 (Wang et al., 2008), which are attributed to the influence of the summer monsoonal circulation that develops over the North China Plain in July. When 

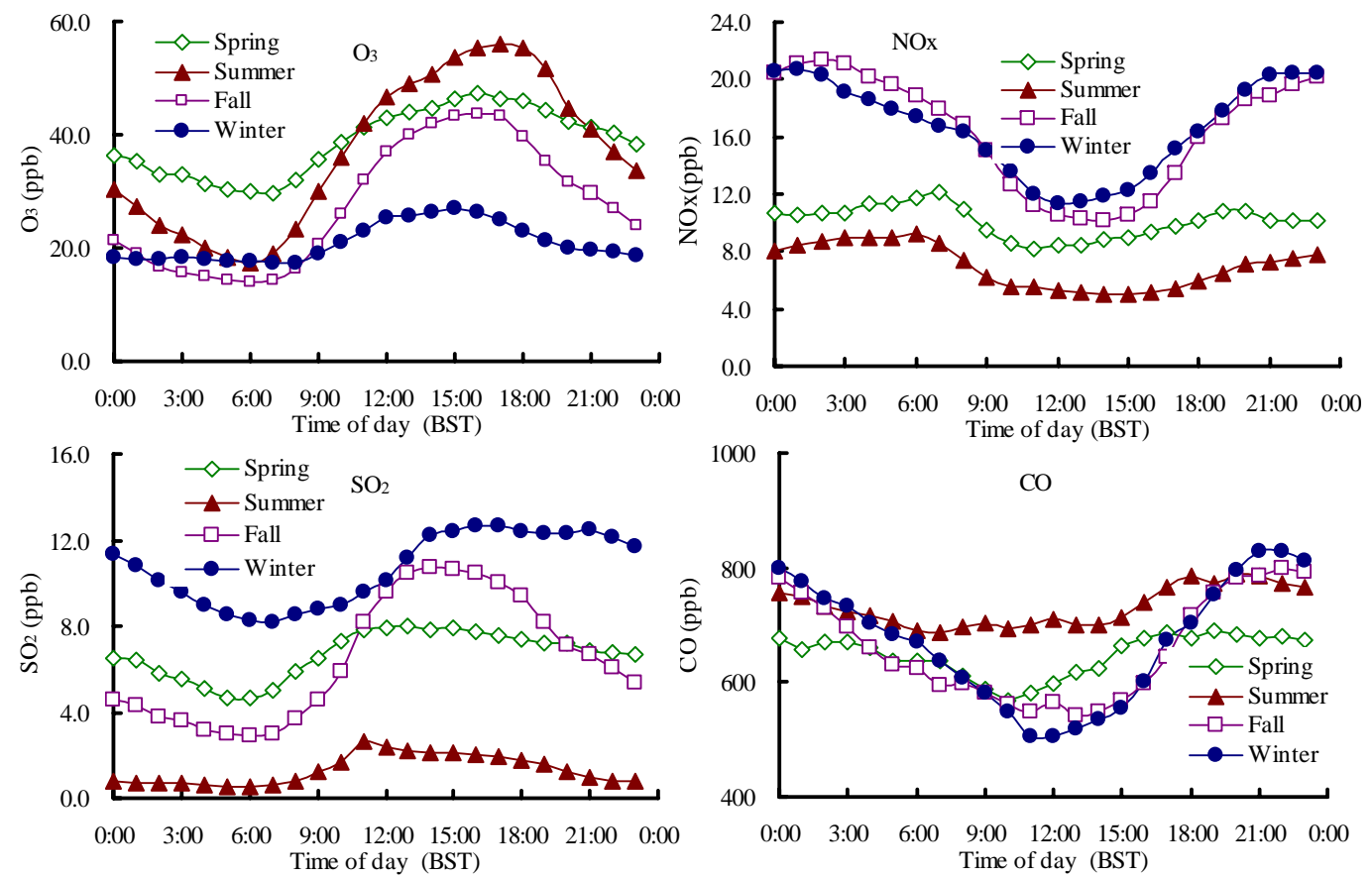

Fig.3. Averaged diurnal variations of trace gases for four seasons at SDZ during 2003-2006.

Fig. 3. Averaged diurnal variations of trace gases for four seasons at SDZ during 2003-2006.

summer monsoonal circulation develops, more air masses from southwest are transported to SDZ. These air masses containing much higher concentrations of pollutants from Beijing city and other parts of the North China Plain can cause elevated background levels of pollutants at SDZ. The observed data of wind and CO in summer months of 2006 shows that the average $\mathrm{CO}$ levels and even the wind speeds from SW-W sector were not much different between June and July, but in July the frequencies of wind from this sector were much more than those in June. Therefore, it is likely that the higher monthly mean of CO in July than in June was related to more frequent transport of CO-rich air from the SSW-W sector.

\subsection{Diurnal variations}

Diurnal variation of atmospheric species gives insight into the interplay of emission and chemical and physical processes operating on a diurnal cycle (Ma et al., 2002b). The average diurnal variations of $\mathrm{O}_{3}, \mathrm{NO}_{\mathrm{x}}, \mathrm{SO}_{2}$, and $\mathrm{CO}$ at $\mathrm{SDZ}$ in different seasons are shown in Fig. 3. The diurnal patterns of $\mathrm{O}_{3}$ for all seasons look similar, with minima and maxima in the early morning and afternoon, respectively.

There are two noticeable differences in the diurnal patterns, i.e., the diurnal amplitude and the peak time. The largest diurnal amplitude occurred in summer ( $38.3 \mathrm{ppbv})$, followed by fall (29.8 ppbv), spring (17.6 ppbv), and winter $(9.5 \mathrm{ppbv})$, respectively. The $\mathrm{O}_{3}$ concentration peaked in winter, spring/fall, and summer at 15:00, 16:00, and 17:00
Beijing Standard Time, respectively. The late peaking time is believed to be a result of transport of $\mathrm{O}_{3}$ and precursors from urban area to SDZ.

The diurnal cycles of $\mathrm{NO}_{\mathrm{x}}$ show valleys around noon and higher values during the nighttime. This phenomenon can be attributed to the day-night differences in the chemical removal of $\mathrm{NO}_{\mathrm{x}}$ and the height of the mixing layer. The diurnal variations of $\mathrm{NO}_{\mathrm{x}}$ for winter and fall show little difference between each other, with the maximum of $\mathrm{NO}_{\mathrm{x}}$ being about two-fold of the minimum, suggesting that the vertical mixing is an important factor for the observed diurnal variation as photochemical removal is much slower in these seasons than in the warmer seasons. The concentrations of $\mathrm{NO}_{\mathrm{x}}$ in summer and spring were significantly lower than those in winter and fall at corresponding time of day, particularly during the night. The diurnal amplitudes of $\mathrm{NO}_{\mathrm{x}}$ in summer (4.2 ppbv) and spring ( $3.9 \mathrm{ppbv}$ ) were much smaller than those in winter (9.4 ppbv) and fall (11.3 ppbv).

The diurnal variations of $\mathrm{SO}_{2}$ for all seasons were inconsistent with those of $\mathrm{NO}_{\mathrm{x}}$. The diurnal patterns look like those of $\mathrm{O}_{3}$, with minimal values in the early morning and maximal values in the afternoon or around noon. An important difference between the diurnal patterns of $\mathrm{SO}_{2}$ and those of $\mathrm{O}_{3}$ is that the average peaking time for $\mathrm{SO}_{2}$ was at the earliest in summer, followed by spring, fall, and winter, respectively, a reversed sequence of the peaking time for $\mathrm{O}_{3}$. The diurnal patterns of $\mathrm{SO}_{2}$ may indicate the existence of a higher $\mathrm{SO}_{2}$ layer above the nighttime and early morning 
Table 3. Monthly frequency occurrence of each type of air mass arriving at SDZ in 2004, 2005, and 2006.

\begin{tabular}{lllllllllllllll}
\hline Year & Air mass type & Jan & Feb & Mar & Apr & May & Jun & Jul & Aug & Sep & Oct & Nov & Dec & $\%$ \\
\hline \multirow{2}{*}{2004} & Cluster 1 & 23 & 16 & 26 & 55 & 43 & 104 & 86 & 85 & 71 & 56 & 23 & 31 & 42.9 \\
& Cluster 2 & 10 & 11 & 13 & 7 & 2 & 3 & 3 & 3 & 7 & 21 & 15 & 9 & 7.2 \\
& Cluster 3 & 15 & 26 & 44 & 14 & 10 & 0 & 2 & 4 & 10 & 22 & 42 & 28 & 15.0 \\
& Cluster 4 & 37 & 47 & 23 & 10 & 30 & 0 & 1 & 4 & 8 & 8 & 17 & 15 & 13.9 \\
& Cluster 5 & 18 & 16 & 18 & 34 & 39 & 13 & 32 & 28 & 24 & 17 & 23 & 40 & 20.9 \\
2005 & Cluster 1 & 13 & 19 & 18 & 21 & 60 & 75 & 86 & 97 & 78 & 40 & 21 & 13 & 37.1 \\
& Cluster 2 & 17 & 24 & 17 & 24 & 9 & 18 & 7 & 1 & 11 & 24 & 28 & 24 & 14.0 \\
& Cluster 3 & 53 & 45 & 38 & 20 & 19 & 6 & 12 & 2 & 10 & 35 & 63 & 30 & 22.8 \\
& Cluster 4 & 37 & 14 & 44 & 47 & 25 & 7 & 8 & 0 & 4 & 15 & 8 & 51 & 17.8 \\
& Cluster 5 & 4 & 10 & 7 & 8 & 11 & 14 & 11 & 24 & 17 & 10 & 0 & 5 & 8.3 \\
2006 & Cluster 1 & 41 & 35 & 29 & 46 & 86 & 73 & 103 & 90 & 73 & 69 & 28 & 22 & 47.6 \\
& Cluster 2 & 41 & 23 & 17 & 12 & 2 & 9 & 2 & 3 & 4 & 10 & 29 & 39 & 13.1 \\
& Cluster 3 & 4 & 14 & 18 & 23 & 6 & 3 & 0 & 0 & 1 & 2 & 27 & 4 & 7.0 \\
& Cluster 4 & 20 & 33 & 46 & 13 & 9 & 17 & 7 & 3 & 23 & 14 & 18 & 43 & 16.9 \\
& Cluster 5 & 18 & 7 & 14 & 26 & 21 & 18 & 12 & 28 & 19 & 29 & 18 & 15 & 15.4 \\
\hline
\end{tabular}

inversion. The fact that $\mathrm{SO}_{2}$ peaks earlier in the warmer seasons than the colder seasons support this point because the vertical mixing develops more quickly in the warmer seasons, so that the surface level of $\mathrm{SO}_{2}$ increases more quickly, leading to earlier peaking of $\mathrm{SO}_{2}$ in the warmer season than colder seasons. Possible sources of this higher $\mathrm{SO}_{2}$ layer may be high chimneys in factories and power plants, the major $\mathrm{SO}_{2}$ emission sources in North China. Additional measurements and modeling studies are necessary for a more robust explanation to the observed diurnal variations of $\mathrm{SO}_{2}$.

As can be seen in Fig. 3, the diurnal variations of $\mathrm{CO}$ for different seasons look similar to those of $\mathrm{NO}_{\mathrm{x}}$, with lower values during the daytime and higher values during the nighttime. The diurnal amplitudes of $\mathrm{CO}$ in winter and fall were much larger than those in summer and spring, as seen in the diurnal variations of $\mathrm{NO}_{\mathrm{x}}$. Unlike the case of $\mathrm{NO}_{\mathrm{x}}$, the average concentrations of $\mathrm{CO}$ in summer and spring did not drop to low levels so that there was no large seasonal difference in the average $\mathrm{CO}$ concentration. In summer, the average $\mathrm{CO}$ concentration changed little with the time of day, showing only a small diurnal variation. As mentioned in the previous section, more intense biomass burning activities and southwesterly winds were responsible for higher CO concentrations. Due to the mountain topography, southwesterly winds dominate during the daytime, favoring the transport of pollutants from the urban area of Beijing to SDZ. Similar results were obtained at a rural site north of Beijing (Wang et al., 2006).
3.4 Air mass backward trajectories and corresponding pollutant concentrations

The long-range transport of air pollution has been the topic of scientific research for several decades, and the importance of long-range transport has been increasingly recognized (Cape et al., 2000; Kim et al., 2005; Ma et al., 2002a, b; Meng et al., 2007; Nolle et al., 2002; Pongkiatkul and Kim Oanh, 2007). To gain an insight into the impact of transport on the reactive gases at SDZ, 72-h air mass backward trajectories were calculated using the HYSPLIT 4 model (HYbrid Single-Particle Lagrangian Integrated Trajectory model version 4.7, http: //www.arl.noaa.gov/ready/hysplit4.html; Draxler and Hess, 1998). The trajectory calculations were done four times each day from 2004 to 2006, with the start times of 00:00, 06:00, 12:00, and 18:00 UTC, respectively. The trajectories were clustered for 2004, 2005, and 2006, respectively, using the cluster analysis function integrated in the HYSPLIT 4 model. Figure 4 shows the results of the cluster analysis, including cluster means and the proportions of different clusters. The trajectories of each year can be grouped into five major clusters. As can be seen in Fig. 4, the cluster means did not vary much from year to year, with cluster 1 indicating air masses from the North China Plain region, cluster 2 from Mongolia or Inner Mongolia passing over Shanxi Province and Hebei Province, clusters 3 and 4 from high altitudes (above $880 \mathrm{~m}$ ) of Mongolia and Russia passing over Inner Mongolia and Hebei Province, and cluster 5 from Mongolia passing over Inner Mongolia and Hebei Province.

Based on the statistics, in all the years, cluster 1 was the most important for the SDZ site, contributing 37\%-48\% of air masses. The contributions from clusters 2 to 5 varied largely from year to year. The year-to-year variations in the proportions of different clusters reflect partly the climato- 

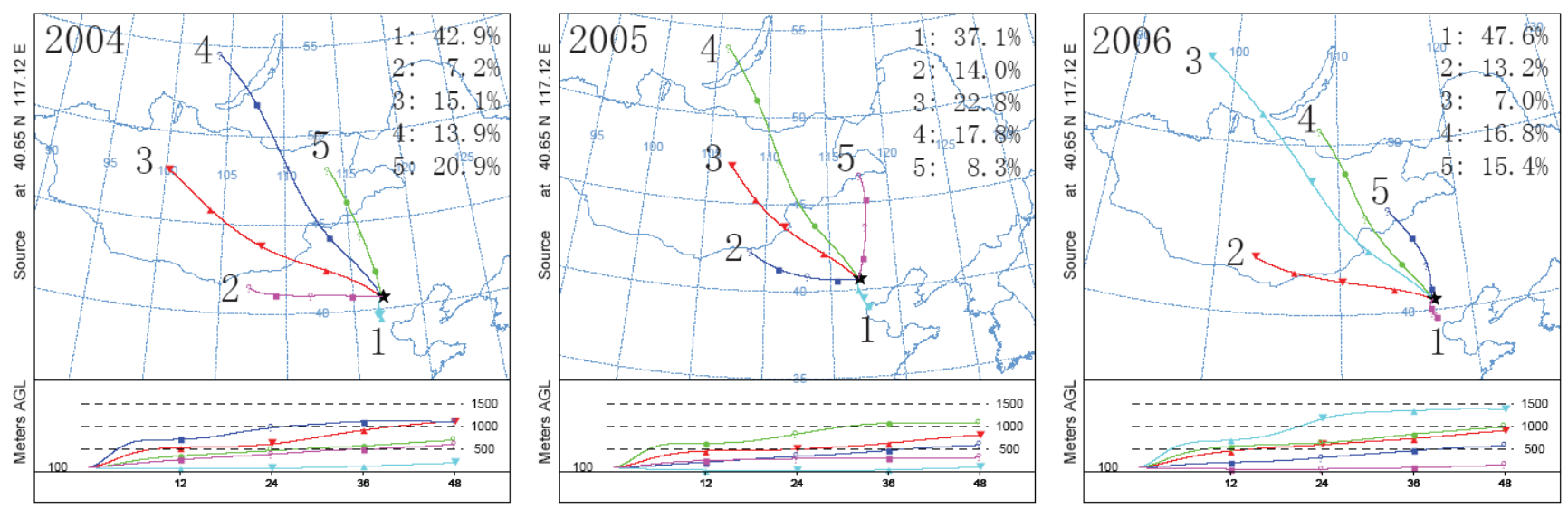

Fig. 4. Air mass backward trajectories for $100 \mathrm{~m}$ above ground at SDZ in 2004, 2005, and 2006. The proportions of different clusters are shown in the upper-right corner of each figure.

Table 4. Statistics of average concentrations of gaseous pollutants for each type of air mass arriving at SDZ, China.

\begin{tabular}{llllll}
\hline Year & Air mass type & $\begin{array}{l}\mathrm{O}_{3} \\
\mathrm{ppbv}\end{array}$ & $\begin{array}{l}\mathrm{NO}_{\mathrm{x}} \\
\mathrm{ppbv}\end{array}$ & $\begin{array}{l}\mathrm{SO}_{2} \\
\mathrm{ppbv}\end{array}$ & $\begin{array}{l}\mathrm{CO} \\
\mathrm{ppbv}\end{array}$ \\
\hline \multirow{2}{*}{2004} & Cluster 1 & 36.6 & 17.6 & 7.9 & \\
& Cluster 2 & 21.9 & 26.2 & 13.7 & \\
& Cluster 3 & 21.0 & 14.9 & 4.9 & \\
& Cluster 4 & 28.5 & 4.8 & 0.9 & \\
& Cluster 5 & 26.6 & 10.6 & 3.5 & 611 \\
& Cluster 1 & 36.4 & 12.2 & 6.4 & 328 \\
& Cluster 2 & 31.7 & 17.7 & 13.9 & 204 \\
& Cluster 3 & 27.7 & 10.4 & 5.0 & 307 \\
& Cluster 4 & 32.7 & 5.2 & 2.1 & 1001 \\
& Cluster 5 & 27.4 & 7.7 & 3.2 & 286 \\
& Cluster 1 & 34.0 & 14.4 & 9.0 & 325 \\
& Cluster 2 & 22.1 & 19.1 & 11.1 & 556 \\
\hline
\end{tabular}

logic differences in the wind systems over the Northeast Asia region, which can influence the transport of pollutants to the SDZ area. To know the seasonal variations in the trajectories, monthly frequency occurrence of each type of air mass arriving at SDZ were calculated and are shown in Table 3. Based on this table, trajectories in cluster 1 can occur in any month but mostly in the summer months, trajectories in clusters 2-4 occur mainly in colder months, and trajectories in cluster 5 seem to be randomly distributed over the year.

Since the emission sources of pollutants are unevenly distributed in the areas surrounding the SDZ site, air masses from different directions contain different levels of pollutants. To characterize the dependences of the pollutants concentrations on air masses, statistics of hourly average concentrations of gaseous pollutants were made for correspond- ing clusters of backward trajectories and are summarized in Table 4. Large differences in the concentrations of primary pollutants exist among the clusters, with cluster 1 corresponding to the highest $\mathrm{CO}$ levels and higher $\mathrm{NO}_{\mathrm{x}}$ and $\mathrm{SO}_{2}$ levels, cluster 2 corresponding to the highest $\mathrm{NO}_{\mathrm{x}}$ and $\mathrm{SO}_{2}$ levels and higher $\mathrm{CO}$ levels.

Since cluster 1 represents air masses originating from the North China Plain region, which are quite polluted by industrial, vehicular, and biomass burning emissions, it is not surprising that the highest $\mathrm{CO}$ levels and higher $\mathrm{NO}_{\mathrm{x}}$ and $\mathrm{SO}_{2}$ were observed in this cluster of air mass. The maximum occurrence of cluster 1 in summer (Table 3 ), together with the highest CO level, may be responsible for the enhanced CO level in summertime (see Sect. 3.2). Air masses in cluster 2 traveled over China's key coal mining and power 
generation regions in Inner Mongolia, Shanxi Province, and Hebei Province (e.g., Datong, Zhangjiakou, etc.). This explains the highest $\mathrm{NO}_{\mathrm{x}}$ and $\mathrm{SO}_{2}$ levels corresponding to cluster 2 (Table 4). Although the occurrences of cluster 2 air masses were less than $15 \%$ for the whole year, it could be higher than $20 \%$ and even $30 \%$ in some winter months, contributing to the high concentrations of $\mathrm{NO}_{\mathrm{x}}$ and $\mathrm{SO}_{2}$ at $\mathrm{SDZ}$ in winter. The data in Table 4 suggest that the $\mathrm{NO}_{\mathrm{x}}, \mathrm{SO}_{2}$, and $\mathrm{CO}$ concentrations corresponding to clusters 3 and 4 were low if not the lowest ones. This is attributable to the less polluted air over the northwest sector and its higher traveling heights and velocities. Cluster 5 represents air masses that traveled over a relatively clean sector at lower heights and velocities, corresponding to median levels of $\mathrm{NO}_{\mathrm{x}}$ and $\mathrm{CO}$ and fairly lower levels of $\mathrm{SO}_{2}$.

The dependence of the concentration of surface $\mathrm{O}_{3}$ on air masses was not as strong as those of primary pollutants, as shown in Table 4. However, the $\mathrm{O}_{3}$ level corresponding to cluster 1 was always highest in all the years, suggesting that pollutants from the North China Plain region contribute most significantly to the $\mathrm{O}_{3}$ level at SDZ.

\section{Conclusions}

In this paper we present measurements of $\mathrm{O}_{3}, \mathrm{NO}_{\mathrm{x}}, \mathrm{SO}_{2}$, and $\mathrm{CO}$ made at the Shangdianzi background station in North China from September 2003 to December 2006. Based on these measurements, the annual mean concentrations were in the range of 30.1-32.8 ppbv for $\mathrm{O}_{3}, 11.0-14.5 \mathrm{ppbv}$ for $\mathrm{NO}_{\mathrm{x}}$, 5.9-7.6 ppbv for $\mathrm{SO}_{2}$, and 586-742 ppbv for CO. The levels of $\mathrm{NO}_{\mathrm{x}}, \mathrm{SO}_{2}$ and $\mathrm{CO}$ at $\mathrm{SDZ}$ were close or comparable to those observed at some other background sites in polluted regions of the similar latitudes, such as Lin'an, China, Burgas and Pleven, Bulgaria, etc., coinciding with the fact that Shangdianzi is a background site representing North China with large population and consumption of fossil fuels and biofuels.

The concentrations of $\mathrm{O}_{3}, \mathrm{NO}_{\mathrm{x}}, \mathrm{SO}_{2}$ and $\mathrm{CO}$ at the SDZ station showed clear seasonal and diurnal variations. The average seasonal variation of $\mathrm{O}_{3}$ shows primary and secondary peaks in June and September, respectively, reflecting the contribution of photochemical production to $\mathrm{O}_{3}$ at SDZ during summer and autumn and the influences of Asian monsoon in July and August. However, the year-to-year alternation in the meteorological conditions can cause some year-to-year changes in the seasonal pattern of $\mathrm{O}_{3}$.

The seasonal variations of $\mathrm{NO}_{\mathrm{x}}$ and $\mathrm{SO}_{2}$, which show maxima in winter and minima in summer, coincide with the influences of photochemistry and regional climate (cold/dry winter and hot/humid summer) in the areas surrounding SDZ. However, the seasonal pattern of $\mathrm{CO}$ does not consist with those of other primary gases $\left(\mathrm{NO}_{\mathrm{x}}\right.$ and $\left.\mathrm{SO}_{2}\right)$, with elevated $\mathrm{CO}$ levels in some summer months. Intensive biomass burning in the North China Plain region, in combination with the transport of regional pollution by more frequent southwesterly winds, is believed to be the cause for this discrepancy. The diurnal cycles of $\mathrm{O}_{3}$ in different seasons show peaks between 15:00 and 18:00, a few hours later than those in the urban area of Beijing, suggesting that local production of $\mathrm{O}_{3}$ is less important than the transport of photochemical aged plume. The diurnal variation of $\mathrm{SO}_{2}$ shows an unusual pattern, with higher concentrations during the daytime and lower concentrations during the nighttime. This pattern is completely different from those of $\mathrm{NO}_{\mathrm{x}}$ and $\mathrm{CO}$ and does not coincide with the common view. It is hypothesized that there is a $\mathrm{SO}_{2}$-rich layer above the nighttime and early morning. This hypothesis remains to be tested in the future.

Backward trajectories of air masses were calculated and analyzed in combination with corresponding pollutant concentrations. Based on the results of this analysis, air masses from the North China Plain region contain the highest concentration of $\mathrm{CO}$ and higher concentrations of $\mathrm{NO}_{\mathrm{x}}$ and $\mathrm{SO}_{2}$, and cause the highest $\mathrm{O}_{3}$ concentration; air masses traveling over the coal mining and power generation regions west of SDZ contain the highest concentrations of $\mathrm{NO}_{\mathrm{x}}$ and $\mathrm{SO}_{2}$ and higher concentration of $\mathrm{CO}$. Therefore, transport of air masses from these regions is responsible for the high concentrations of the gaseous pollutants.

Acknowledgements. This work is supported by National Basic Research Program of China (2005CB422202) and by the Ministry of Science and Technology of China (Project No. 2001DIA10009) and (Grant No. 2004DFA06100). We thank the staff of Shangdianzi Regional Background Station for carrying out the routine observations.

Edited by: J. G. Murphy

\section{References}

Cape, J. N., Methven, J., and Hudson, L. E.: The use of trajectory cluster analysis to interpret trace gas measurements at Mace Head, Ireland, Atmos. Environ., 34, 3651-3663, 2000.

Ding, A. J., Wang, T., Thouret, V., Cammas, J.-P., and Nédélec, P.: Tropospheric ozone climatology over Beijing: analysis of aircraft data from the MOZAIC program, Atmos. Chem. Phys., 8, 1-13, 2008, http://www.atmos-chem-phys.net/8/1/2008/.

Ding, G. A., Meng, Z. Y., Yu, H. Q., Wang, S. F., Wen, D. Y., Wang, X. Y.: Measurement and research on ABL air pollution in Beijing, J. Appl. Meteor. Sci., 13 (special), 82-93, , 2002 (in Chinese with English abstract).

Draxler, R. R. and Hess, G. D.: An Overview of the Hysplit_4 modeling system for trajectories, dispersion, and deposition, Aust. Meteorol. Mag., 47, 295-308, 1998.

Fischer, H., Kormann, R., Klüpfel, T., Gurk, Ch., Königstedt, R., Parchatka, U., Mühle, J., Rhee, T. S., Brenninkmeijer, C. A. M., Bonasoni, P., and Stohl, A.: Ozone production and trace gas correlations during the June 2000 MINATROC intensive measurement campaign at Mt. Cimone, Atmos. Chem. Phys., 3, 725-738, 
2003 ,

http://www.atmos-chem-phys.net/3/725/2003/.

Forster, P., Ramaswamy V., Artaxo P., et al.: Changes in atmospheric constituents and in radiative forcing, in: Climate Change 2007: The Physical Science Basis, Contribution of Working Group I to the Fourth Assessment Report of the Intergovernmental Panel on Climate Change, 2007.

Hao, J. M., Wang, L. T., Li, L., Hu, J. N., and Yu, X. C.: Air pollutants contribution and control strategies of energy-use related sources in Beijing, Sci. China Ser. D., 48 (Supplement II), 138146, 2005.

Jaffe, D., Price, H., Parrish, D., Goldstein, A., and Harris, J.: Increasing background ozone during spring on the west coast of North America, Geophys. Res. Lett., 30(12), 1613, doi:10.1029/2003GL017024, 2003.

Jaffe, D. and Ray, J.: Increase in surface ozone at rural sites in the western US, Atmos. Environ., 41, 5452-5463, 2007.

Kim, J., Yoon, S. C., Jefferson, A., Zahorowski, W., and Kang, C. H.: Air mass characterization and source region analysis for the Gosan super-site, Korea, during the ACE-Asia 2001 field campaign, Atmos. Environ., 39, 6513-6523, 2005.

Lelieveld, J., Berresheim, H., Borrmann, S., Crutzen, P. J., Dentener, F. J., Fischer, H., Feichter, J., Flatau, P., Heland, J., Holzinger, R., Kormann, R., Lawrence, M. B., Levin, Z., Markowicz, K., Mihalopoulos, N., Minikin, A., Ramanthan, V., de Reus, M., Roelofs, G. J., Scheeren, H. A., Sciare, J., Schlager, H., Schulz, M., Siegmund, P., Steil, B., Stephanou, E. G., Stier, P., Traub, M., Warneke, C., Williams, J., and Ziereis, H.: Global air pollution crossroads over the Mediterranean, Science, 298, 794-799, 2002.

Lin, W., Xu, X., Zhang, X., and Tang, J.: Contributions of pollutants from North China Plain to surface ozone at the Shangdianzi GAW Station, Atmos. Chem. Phys., 8, 5889-5898, 2008,

http://www.atmos-chem-phys.net/8/5889/2008/.

Ma, J., Liu, H., and Hauglustaine, D.: Summertime tropospheric ozone over China simulated with a regional chemical transport model, Part 1. Model description and evaluation, J. Geophys. Res., 107(D22), 4660, doi:10.1029/2001JD001354, 2002a.

Ma, J., Richter, A., Burrows, P. B., Nüß, H., and Van Aardenne, J. A.: Comparison of model-simulated tropospheric $\mathrm{NO}_{2}$ over China with GOME-satellite data, Atmos. Environ., 40, 593-604, 2006.

Ma, J. and van Aardenne, J. A.: Impact of different emission inventories on simulated tropospheric ozone over China: a regional chemical transport model evaluation, Atmos. Chem. Phys., 4, 877-887, 2004, http://www.atmos-chem-phys.net/4/877/2004/.

Ma, J., Zhou, X., and Hauglustaine, D.: Summertime tropospheric ozone over China simulated with a regional chemical transport model. Part2. Source contribution and budget, J. Geophys. Res., 107(D22), 4612, doi:10.1029/2001JD001355, 2002 b.

Marenco, A. H., Nedelec, G. P., and Pages, J. P.: Evidence of a longterm increase in tropospheric ozone from Pic du Midi data series, Consequences: Positive radiative forcing, J. Geophys. Res., 99, 16617-16632, 1994.

Meng Z. Y., Jiang, X. M., Yan, P., Lin, W. L., Zhang, H. D., and Wang, Y.: Characteristics and sources of $\mathrm{PM}_{2.5}$ and carbonaceous species during winter in Taiyuan, China, Atmos. Environ., 41, 6901-6908, 2007.
Meng Z.Y., Ding, G.A., Tang, J., and Wang, S.F.: Characteristics of Trace Gases at Shangdianzi Background Station in autumn and winter in Beijing, Meteorol. Sci. Technol., 35(4), 548-557, 2007 (in Chinese with English abstract).

Meng Z. Y., Ding, G. A., Xu, X. B., Xu, X. D., Yu, H. Q., and Wang, S. F.: Vertical distributions of $\mathrm{SO}_{2}$ and $\mathrm{NO}_{2}$ in the lower atmosphere in Beijing urban areas, China, Sci. Tot. Environ., 390, 457-466, 2008.

Meng, Z. Y., Ding, G. A., Yu, H. Q., and Wang, S. F.: The preliminary research on the vertical distribution of $\mathrm{SO}_{2}$ and $\mathrm{NO}_{2}$ concentrations in the northern part of Beijing, J. Appl. Meteor. Sci 13(Suppl), 109-112, 2002 (in Chinese with English abstract).

Nolle, M., Ellul, R., Heinrich, G., and Güsten, H.: A longterm study of background ozone concentrations in the central Mediterranean-diurnal and seasonal variations on the island of Gozo, Atmos. Environ., 36, 1391-1402, 2002.

Ostro, B.: Outdoor air pollution: Assessing the environmental burden of disease at national and local levels, Geneva, World Health Organization, WHO Environmental Burden of Disease Series, No. 5, 2004.

Pongkiatkul, P. and Oanh, N. T. K.: Assessment of potential longrange transport of particulate air pollution using trajectory modeling and monitoring data, Atmos. Res., 85, 3-17, 2007.

Tang, J., Wang, M. L., Cheng, H. B., Ding, G. A., Yu, X. M., Zhou, H. G., and Liu, G. P.: Variation characteristics of ambient NMHCs at Shangdianzi and Lin'an Regional GAW sites, Accta Meteorologica Sinica., 20(1), 334-341, 2007.

Wang, H. X., Tang, X. Y., Wang, M. L., Yan, P., Wang, T., Shao, K. S., Zeng, L. M., and Du, H. F.: Characteristics of observed trace gaseous pollutants in the Yangtze Delta, Sci. China., 46, 397-404, 2003a.

Wang, T., Ding, A. J., Gao, J., and Wu, W. S.: Strong ozone production in urban plumes from Beijing, China, Geophys. Res. Lett., 33, L21806, doi:10.1029/ 2006GL027689, 2006.

Wang, T., Cheung, V. T. F., Lam, K. S., Kok, G. L., and Harris, J. M.: The characteristics of ozone and related compounds in the boundary layer of the south China coast: temporal and vertical variations during autumn season, Atmos. Environ., 35, 27352746, 2001a.

Wang, T., Cheung, V. T. F., Anson, M., and Li, Y. S.: Ozone and related gaseous pollutants in the boundary layer of eastern China: Overview of the recent measurements at a rural site, Geophys. Res. Lett., 28, 2373-2376, 2001b.

Wang, T., Poon, C. N. Y., Kwok, H., and Li, Y. S.: Characterizing the temporal variability and emission patterns of the pollution plumes in the Pearl River Delta of China, Atmos. Environ., 37, 3539-3550, 2003b.

Wang, W. X. and Wang, T.: On the origin and the trend of acid rain precipitation in China, Water Air Soil Poll., 85, 2295-2300, 1995.

Wang, Y., McElroy, M. B., Munger, J. W., Hao, J., Ma, H., Nielsen, C. P., and Chen, Y.: Variations of $\mathrm{O} 3$ and $\mathrm{CO}$ in summertime at a rural site near Beijing, Atmos. Chem. Phys., 8, 6355-6363, available at: http://www.atmos-chem-phys.net/8/6355/2008, 2008.

WMO: World Data Centre for Greenhouse Gases (WDCGG) data summary, WDCGG No. 31, 2007.

Xie, S. D., Yu, T., Zhang, Y. H., Zeng, L. M., Qi, L., and Tang X. Y.: Characteristics of $\mathrm{PM}_{10}, \mathrm{SO}_{2}, \mathrm{NO}_{\mathrm{x}}$ and $\mathrm{O}_{3}$ in ambient air during the dust storm period in Beijing, Sci. Tot. Environ., 345, 
153-164, 2005.

Xu, X., Lin, W., Wang, T., Yan, P., Tang, J., Meng, Z., and Wang, Y.: Long-term trend of surface ozone at a regional background station in eastern China 1991-2006: enhanced variability, Atmos. Chem. Phys., 8, 2595-2607, 2008,

http://www.atmos-chem-phys.net/8/2595/2008/.

Xu, X. D., Shi, X. H., Xie, L. A., Ding, G. A., Miao, Q. J., Ma, J. Z., and Zheng, X. D.: Spatial character of the gaseous and particulate state compound correlation of urban atmospheric pollution in winter and summer, Sci. China Ser. D., 48 (Supplement II), 64-79, 2005.
Yan, P., Tang, J., Huang, J., Mao, J. T., Zhou, X.J., Liu, Q., Wang, Z. F., and Zhou, H. G.: The measurement of aerosol optical properties at a rural site in Northern China, Atmos. Chem. Phys., 8, 2229-2242, 2008, http://www.atmos-chem-phys.net/8/2229/2008/.

Zhao, D., Xiong, J., Xu, Y., Chan, W. H.: Acid rain in southwestern China, Atmos. Environ., 22, 349-358, 1988. 